\title{
A poesia eisensteiniana de Vinicius de Moraes: 0 olhar cinematográfico de uma poética
}

\author{
Bruno Araujo Salgueiro ${ }^{\mathrm{i}}$
}

\begin{abstract}
RESUMO
Divido em duas partes, este artigo procura analisar algumas das técnicas do cineasta russo Sergei Eisenstein à luz da poética de Vinicius de Moraes, sobretudo as estudadas e divulgadas pelo poeta brasileiro em suas crônicas de cinema para os jornais de sua época. Para tanto, na primeira parte do artigo, o poema "Tríptico da morte de Sergei Mikhailovitch Eisenstein" (1957), de Vinicius de Moraes, será utilizado como suporte da análise. Além disso, parte da biografia do cineasta será contemplada para melhor apreciação do avanço e do uso das técnicas artísticas de Eisenstein na composição de seus filmes. A segunda parte do artigo destaca os aspectos sociais e políticos a partir de uma leitura intermidiática do poema "O operário em construção" (1959) em diálogo com o filme A greve (1925), de Sergei Eisenstein.
\end{abstract}

Palavras-chave: Vinicius de Moraes. Sergei Eisenstein. Poesia. Cinema. Crítica.

\begin{abstract}
Divided into two parts, this article aims to analyze some of the techniques of Russian filmmaker Sergei Eisenstein in the light of Vinicius de Moraes' poetics, especially those techniques studied and disseminated by the Brazilian poet in his reviews for the newspapers of his time. To this end, the first part of the article presents the poem "Tríptico da morte de Sergei Mikhailovitch Eisenstein" (1957), by Vinicius de Moraes, which will be used as a support for the analysis. In addition, part of the filmmaker's biography is included for a better appreciation of the advancement and use of Eisenstein's artistic techniques in the composition of his films. The second part of the article highlights the social and political aspects by making an intermedia reading of the poem "O operário em construção" (1959) in dialogue with the film A greve (1925), by Sergei Eisenstein.
\end{abstract}

Keywords: Vinicius de Moraes. Sergei Eisenstein. Poetry. Cinema. Criticism.

\footnotetext{
${ }^{\mathrm{i}}$ Doutorando em Teoria da Literatura e Literatura Comparada pela Universidade do Rio de Janeiro (UERJ). Mestre em Literatura Brasileira pela Universidade Federal do Rio de Janeiro (UFRJ).

E-mail: brunolitbras@gmail.com
} 


\title{
1. TEORIA DO CINEMA EM "TRÍPTICO NA MORTE DE SERGEI MIKHAILOVITCH EISENSTEIN"
}

Ao se apresentar como o novo colunista de cinema do jornal A Manhã, em 1 de agosto de 1941, Vinicius de Moraes expõe aos leitores sua concepção de cinema com as seguintes palavras:

\begin{abstract}
Creio no Cinema, arte muda, filha da Imagem, elemento original de poesia e plástica infinitas, célula simples de duração efêmera e livremente multiplicável. Creio no Cinema, meio de expressão total em seu poder transmissor e sua capacidade de emoção, possuidor de uma forma própria que lhe é imanente e que, contendo todas as outras, nada lhes deve. Creio no Cinema puro, branco e preto, linguagem universal de alto valor sugestivo, rico na liberalidade e poder de evocação. (MORAES, 1941, p. 5)
\end{abstract}

Como visto acima, Vinicius acreditava na existência do "cinema puro", isto é, no cinema preto e branco, além de totalmente mudo. Isso deve-se ao fato de o poeta entender o cinema como a arte da imagem, que seria a matéria-prima necessária capaz de transmitir todo o significado e emoção que se pudesse buscar por meio de tal arte. Sendo assim, qualquer interferência de outros recursos - como a cor e o som - afetaria a capacidade de expressão que a imagem cinematográfica pode transmitir ao espectador.

Para Vinicius de Moraes, a imagem no cinema não se resume, no entanto, ao produto final disposto para o apreciador da arte. Ela é, antes de tudo, um processo de construção que vai desde a ideia do filme até a transmutação dessa ideia em cinema. Em outras palavras, da decupagem à montagem dos planos capturados pela câmera. É importante destacar, contudo, que todo esse processo de construção do filme deve ser evidenciado pela imagem. Esta seria, então, "a forma própria" da arte cinematográfica, a sua identidade, o que a faz cinema, segundo Vinícius. Neste sentido, talvez o cineasta que mais se aproxime do pensamento de Vinícius de Moraes acerca do que seria realmente a arte de fazer cinema seja o russo Serguei Mikhailovitch Eisenstein.

O cineasta russo começou na dramaturgia ainda na década de 1920, e sua experiência foi adquirida com Meyerhold, diretor que, segundo Vinicius de Moraes $(1941 b, \text { s.p. })^{2}$, “mais largamente ‘cinematizou’ o teatro”. Eisenstein começou seu estágio na equipe de Meyerhold como decorador - cenógrafo -, e tal experiência foi importante na medida em que o permitiu observar que somente atores não muito dotados de talento 
artísticos moldavam-se às ideias de Meyerhold. Essa característica seria muito importante na formação do futuro cineasta (cf. MORAES, 1951) ${ }^{3}$. Em seguida, entrou em outro grupo, Proletkult, lugar que lhe permitiu realizar diversas experiências, como o teatro acrobático, o teatro de arena e o desenvolvimento da base de sua teoria do cinema, que se iniciou por meio de um episódio descrito da seguinte maneira por Jaques Rancière:

\begin{abstract}
No teatro do Proletkult, ainda, durante a preparação de uma peça de Ostrovski, o olhar do diretor teria sido impressionado pelo rosto de um menino que assistia aos ensaios. Aquele rosto imitava, como um espelho, todos os sentimentos e ações representados no palco. Disso teria nascido outro projeto: não se tratava de anular a onipotência da mimese que se lia no rosto da criança, destruindo as ilusões da arte em proveito da vida nova. Era preciso, ao contrário, captar seu princípio, demonstrar seu mecanismo, não para fazer uma demonstração crítica de seu poder de iludir, mas para racionalizar e otimizar seu uso. (RANCIÈRE, 2013, p. 27)
\end{abstract}

Após a encenação de Máscara de gás (1924), de Tretiakov, que foi montada em uma verdadeira fábrica de gás, cuja realidade da fábrica anulou o projeto de encenação da peça, Serguei Eisenstein sentiu necessidade de uma arte nova para colocar em prática seus estudos teóricos (cf. RANCIÈRE, 2013, p. 27). A partir de então, o cineasta russo de vanguarda levou a arte de explorar as possibilidades hermenêuticas da imagem cinematográfica ao seu limite. Eisenstein chamou a atenção para o alto poder sugestivo da imagem e sobretudo do plano ao serem combinados a outras imagens ou planos. $\mathrm{O}$ cineasta levou, portanto, a arte da montagem ao seu grau máximo de expressividade.

Em “Tríptico na morte de Sergei Mikhailovitch Eisenstein”, poema dedicado a Serguei Eisenstein no ano da morte do cineasta, Vinicius de Moraes demonstra a capacidade do russo em fazer do cinema um grande poema. Para tal intento, como poeta, Vinicius transformou seu poema em cinema. Ao utilizar a forma de um tríptico para construir seu poema, Vinicius remete-nos a uma das principais preocupações de Serguei Eisenstein: a exploração das potencialidades de significação das imagens cinematográficas. A partir desse interesse, Eisenstein desenvolveria a teoria da montagem de atrações ou ideológica. Tal técnica consiste em unir dois planos que, isolados, não possuem nenhum significado aparente, mas que, por meio dessa união, geram um terceiro significado, este idealizado e compreensível dentro do contexto fílmico. Dessa maneira, a imagem tomaria para si toda a autonomia significativa, sem a necessidade, portanto, de outras ferramentas que não a própria imagem para construir e desenvolver a mensagem 
que se pretendia passar ao espectador. Como exemplo desse tipo de montagem, podemos destacar dois planos do filme Outubro, de 1928, nos quais aparece, em primeiro plano, o primeiro-ministro russo, Alexander Kerensky, entrando em seu gabinete e, já no segundo plano, a imagem de um pavão abrindo sua calda. Naturalmente, as duas figuras são associadas e então se tem um significado comum ou um traço característico do primeiroministro, que é o personagem central da cena.

Esse cuidado com a forma da construção também se reflete, no poema, em cada parte do tríptico: cada uma é formada por um soneto italiano. Ao utilizar essa forma fixa, Vinicius de Moraes evoca para seu poema todos o cuidado e plasticidade imanentes da obra de Serguei Eisenstein. A primeira parte do tríptico tem como foco a relação de Serguei Eisenstein com a imagem, que aparece, no poema, como o próprio cineasta: "Tu foste a imagem/ em movimento" (MORAES, 2008, p. 164). É interessante observar o uso do enjambement para separar "imagem" de "em movimento", que inicia a segunda estrofe, cuja intenção consiste na representação do próprio movimento da imagem cinematográfica. A correspondência imagem/cineasta relaciona-se à ideia que Vinicius tinha a respeito da criação do filme, que deveria ser realizado por um único artista, como em um poema, inclusive a filmagem. Mesmo os atores, para Vinicius, deveriam exercer uma função secundária ou, ainda, ser uma ferramenta do cineasta utilizada na composição das imagens: "[o] ator em cinema não é um indivíduo que representa, porque ele não é um indivíduo, e ele não representa não" (MORAES, 1951, p. 9). Neste sentido, as duas estrofes finais dessa primeira parte evidenciam e reforçam a ideia de Serguei Eisenstein como aquele capaz de captar e recriar a realidade que aparece nas imagens registradas pela câmera, como se ele estivesse, além disso, tal como as imagens, eternizado em seus filmes:

\author{
Camarada, através dos grandes gelos \\ Imensuráveis. Nunca vi mais belos \\ Céus que esses sob que caminhas, só \\ E infatigável, a despertar o assombro \\ Dos horizontes com tua câmara ao ombro... \\ Spasibo, tovarishch. Khorosho. (MORAES, 2008, p. 164).
}

A câmara daria ao realizador, portanto, o poder de recriar a realidade por meio das imagens, ou seja, enquanto inseridos no tempo e no espaço do filme, nós, espectadores, 
estaríamos inseridos no tempo e no espaço artísticos criado por Eisenstein. É assim que o cineasta torna-se imortal, pois a arte possui uma vida apartada da efemeridade que é a vida real, esta estaria, em contrapartida, externa ao espaço que comporta o conteúdo artístico. É nesse sentido que a segunda parte do poema concentra-se. O eu-lírico irá, assim, destacar todo o caráter concreto e material que as imagens, bem como a história inserida no conteúdo fílmico, possuem:

II

Pelas auroras imobilizadas

No instante anterior; pelos gerais

Milagres da matéria; pela paz

Da matéria; pelas transfiguradas

Faces da História; pelo conteúdo

Da História e em nome de seus grandes idos

Pela correspondência dos sentidos

Pela vida a pulsar dentro de tudo (...). (MORAES, 2008, p. 165)

Esta "vida a pulsar dentro de tudo", encontrada em seus filmes, é tão concreta e real que pode ser percebida e correspondida através dos sentidos, como o verso final da terceira estrofe da segunda parte ilustra bem: "Pelos sons; pelas cores; pela voz".

A terceira parte do tríptico sintetiza tudo o que o eu-lírico pensa a respeito de cinema, que se confunde com a figura de Serguei Eisenstein, à medida que recupera tudo o que foi dito anteriormente sobre o processo de montagem sendo o elemento fundamental para a existência da imagem cinematográfica, como podemos perceber nos versos "a imagem só existe interligada/ À que a antecedeu e à que a sucede" (MORAES, 2008, p. 166) e, na estrofe seguinte:

\author{
O cinema é a presciente antevisão \\ Na sucessão de imagens. O cinema \\ É o que não se vê, é o que não é \\ Mas resulta: a indizível dimensão. (MORAES, 2008, p. 166)
}

Essa “indizível dimensão", vale ressaltar, refere-se à eternidade da arte e a sua capacidade de criar seu próprio espaço, como já dito anteriormente: "O cinema é infinito - não se mede". Nesse sentido, compreende-se a beleza da estrofe seguinte onde se destacam três grandes personagens de seus filmes: Odessa, de O Encouraçado Potemkin (1925), Nevski, de Alexandre Nevski (1938), e Ivan, de Ivan, O Terrível, parte I (1944) e 
Ivan, O Terrível, parte II (1945), que, por meio da câmera de Serguei Eisenstein, ganharam não somente a eternidade como também vida. O cinema seria, dessa maneira, tão grandioso que a existência das escadarias de Odessa, assim como a sua construção, por exemplo, justificar-se-ia pela célebre aparição em umas das cenas de $O$ Encouraçado Potemkin: “Cinema é Odessa, imóvel na manhã/À espera do massacre; é Nevski; é Ivan/O Terrível; és tu, mestre!” (MORAES, 2008, p. 166).

Como o poema, o tríptico termina com um agradecimento em português e em russo. Nota-se que a frase em russo "Spasibo, tovarishch. Khorosho" finaliza todas as estrofes e, no entanto, sua tradução só fica clara nesta última estrofe se o leitor não souber russo. Isso acontece devido à aproximação com o verso anterior, em português, cuja equivalência da construção das formas frasais revela-nos o mistério: "Muito bem, Eisenstein. Muito obrigado./Spasibo, tovarishch. Khorosho" (MORAES, 2008, p. 166). Esse "jogo" com duas línguas completamente diferentes, mas que expressam um significado afim, remete-nos à montagem ideológica ou de atrações, já comentada no início do artigo. Esses últimos versos fazem-nos refletir, ainda, sobre as diferentes manifestações artísticas, como o cinema de Eisenstein e o poema de Vinicius de Moraes, que se harmonizam por meio do fazer poético. Dessa maneira, como evidencia o poema de Vinicius, a poesia é elemento imprescindível para a construção cinematográfica.

\section{A POESIA EM CONSTRUÇÃO DE VINICIUS DE MORAES}

A segunda parte deste artigo tem como objetivo analisar o poema "O operário em construção", de Vinicius de Moraes, sob a luz do filme A greve (1925), de Sergei Eisenstein. Tal análise conjunta é possível devido à admiração de Vinicius pela arte cinematográfica e, mais especificamente, pelo cinema de Eisenstein - admiração comprovada pelas diversas crônicas que o poeta dedicou ao cineasta, tais como "Eisenstein e a teoria do cinema", publicado em 1941, no jornal A Manhã; "Conceito de montagem", publicado em 1951, no jornal Última Hora; “A malquerida”, publicado em 1951, no jornal A Última Hora; bem como o poema "Tríptico na morte de Sergei Mikhailovitch Eisenstein”. Além disso, a validade da leitura conjunta é conferida pelo assunto central das duas obras: a percepção da injustiça, da desigualdade e da consequente exploração dos operários pelos empregadores ou diretores das fábricas, o que, por 
conseguinte, resulta na união dos explorados. Essa união é ilustrada pelo texto de Lenin que introduz o filme A greve: "A força da classe trabalhadora é a organização. Sem organização das massas, o proletariado não é nada. Organizado, é tudo. Ser organizado significa unidade de ação, a unidade da atividade prática".

A primeira cena de $A$ greve inicia-se com uma sobreposição de dois planos distintos: um mostra os operários entrando em uma fábrica e o outro, o diretor da fábrica dando gargalhadas. A associação dos dois planos produz um significado muito claro: o trabalho dos operários é a felicidade do diretor da indústria. Contudo, essa felicidade não corresponde à felicidade dos trabalhadores; ao contrário, estes encontram-se infelizes e injustiçados, pois trabalham em condições deploráveis por um salário extremamente baixo que mal supre as necessidades básicas desses homens. Em vista disso, os operários começam a se organizar para uma greve com o propósito de reivindicar seus direitos, bem como melhores condições de trabalho. Tudo isso ocorre na primeira parte do filme, que é dividido em seis, e, portanto, já se inicia com os operários conscientes da exploração que sofrem. Já o poema "O operário em construção" inicia-se com o trabalhador ainda inconsciente da exploração de seu trabalho, mas que, devido a essa inconsciência, enxerga-se livre. Tal inconsciência dá-se pela não percepção do paradoxo em que consiste a sua liberdade, que é, na verdade, uma escravidão:

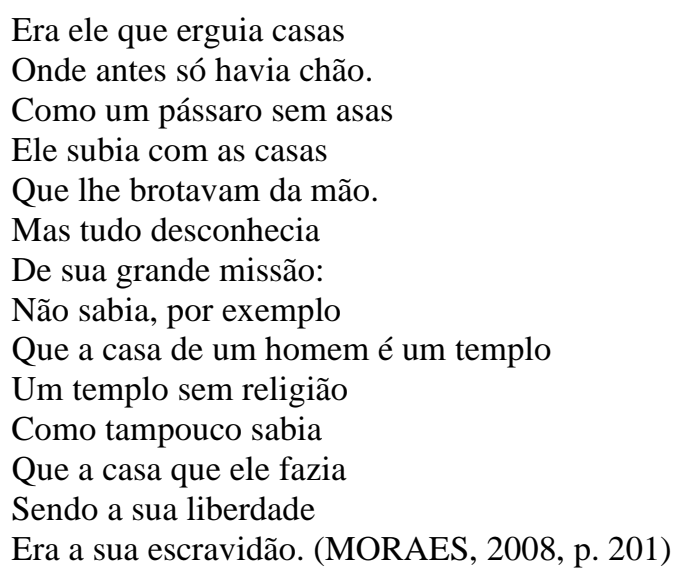

$\mathrm{Na}$ estrofe seguinte, dois temas característicos da classe operária explorada pelo sistema capitalista são destacados: o primeiro refere-se à indefiniçãa do operário, ilustrada pela introdução do artigo indefinido que antecipa o substantivo "operário". Isso ocorre para destacar o vazio desses trabalhadores da construção: esse operário não representa especificamente um operário, mas toda a classe operária, que, alienada devido 
ao desconhecimento do paradoxo citado acima, está vazia semanticamente, distante de saber, por exemplo, do motivo de um tijolo valer mais que um alimento:

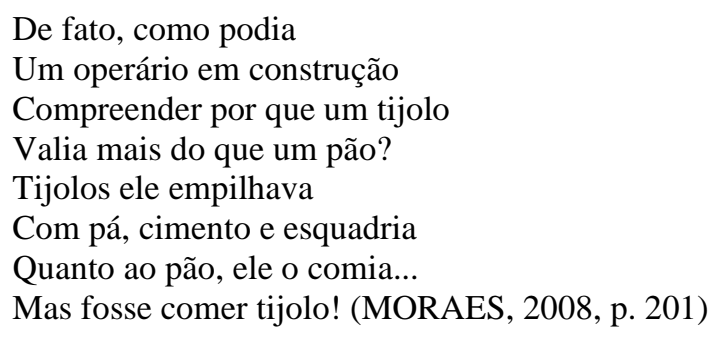

Já o segundo tema refere-se às opções que o atual sistema oferece aos trabalhadores retratados pelo poema. Os operários possuem duas escolhas: trabalho escravo - como destacado na primeira estrofe - ou a vida no crime, que pode gerar uma futura prisão:

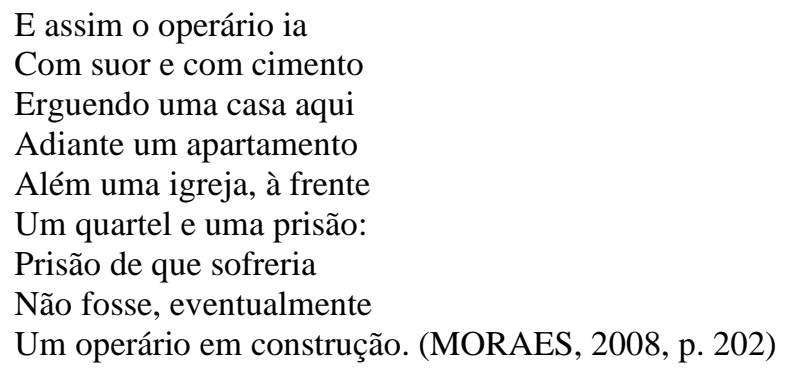

A estrofe seguinte é o momento em que "um operário" deixa de ser introduzido pelo artigo indefino "um" e, ao mesmo tempo, de ser vazio para assim se preencher semanticamente e começar a ser introduzido pelo artigo definido "o". Tal mudança gramatical simboliza formalmente o momento da ruptura com o sistema ou o alumbramento do operário, ou seja, esse trabalhador deixa de ser alienado e percebe "Que o operário faz a coisa/E a coisa o operário" (MORAES, 2008, p. 202). O operário da construção começa a se autoconstruir, percebendo-se como a engrenagem que faz o capitalismo girar e que, dessa maneira, deveria ser visto em primeiro plano. Evidencia-se que o homem é mais importante que a coisa construída, tendo em vista que tudo sai dele, pois, quando alienado, o indivíduo é escravo, consequentemente, de sua própria obra. Além disso, o operário enxergou um mundo à parte desse espaço limitado de exploração, um mundo fora do sistema em que estava inserido, ele enxergou, assim, a dimensão da 
poesia, que, neste sentido, pode-se compreender como a capacidade criadora que lhe é intrínseca. Assim, o operário, como construtor das coisas, era, dessa maneira, um poeta:

\author{
Foi dentro da compreensão \\ Desse instante solitário \\ Que, tal sua construção \\ Cresceu também o operário. \\ Cresceu em alto e profundo \\ Em largo e no coração \\ E como tudo que cresce \\ Ele não cresceu em vão \\ Pois além do que sabia \\ - Exercer a profissão - \\ O operário adquiriu \\ Uma nova dimensão: \\ A dimensão da poesia. (MORAES, 2008, p. 203-204)
}

É nesse ponto que o poema e o filme $A$ greve dialogam de uma forma mais evidente. A partir daqui, começa a luta do operário para ver-se livre da exploração dos empregadores e detentores do poder capitalista. O operário que teve a percepção do paradoxo que rege o sistema capitalista - aquele que percebeu que o trabalho não o liberta, mas escraviza -, começa a compartilhar sua descoberta com seus companheiros de trabalho, formando uma unidade com os demais operários. Cria-se, então, o sentido de classe, e essa definitivamente torna-se o centro do poema, bem como o do filme, que tem na greve um catalisador da luta de classes. Tal luta, no poema, inicia-se com a negação da subserviência do operário, representada pelo "sim" e que agora se transforma em "não":

\footnotetext{
E foi assim que o operário Do edifício em construção Que sempre dizia sim Começou a dizer não.

E aprendeu a notar coisas A que não dava atenção: Notou que sua marmita Era o prato do patrão Que sua cerveja preta Era o uísque do patrão Que seu macacão de zuarte Era o terno do patrão Que o casebre onde morava Era a mansão do patrão Que seus dois pés andarilhos Eram as rodas do patrão Que a dureza do seu dia
} 


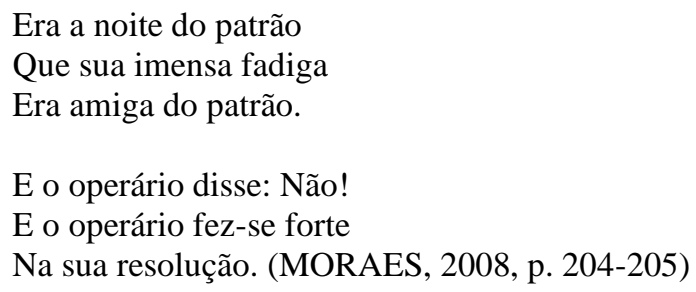

No que se refere à correspondência do trabalho do operário e à crescente felicidade do patrão, a estrofe acima pode ser resumida com uma frase marcante do filme de Eisenstein: "Tudo que sustenta seus tronos é feito pela mão dos operários". O filme ilustra o rompimento - representado pelo "Não!" no poema - do operário com o patrão em uma cena em que dois planos são sobrepostos pela montagem: em um, há a roda que gira e no outro plano, três trabalhadores. Na medida em que os trabalhadores vão cruzando seus braços, a roda aos poucos para de girar e os dois planos são fundidos em um só por meio da montagem. A cena mostra mais do que a relação de interdependência da máquina e do homem, tendo em vista que homem e máquina são um e uma única coisa para os donos das indústrias. No entanto, a máquina é, na verdade, uma criação do homem: basta que ele cruze os brações e cesse seu trabalho para que ela deixe de funcionar e perca sua razão de existir. Dessa forma, pode-se concluir que o significado mais importante desse cruzar de braços, bem como o da luta de classes, seja a tomada para si dessa condição de superioridade perante a máquina e não o oposto, que, além da relação de interdependência, também faz parte da visão deturpada do patrão detentor do maquinário.

Contudo, esse gesto não fica sem resposta do patrão ou de funcionários de altos cargos, como os delatores do poema - "As bocas da delação/ Começaram a dizer coisas/ Aos ouvidos do patrão" (MORAES, 2008, p. 205) - ou chefes de setores das fábricas retratados no filme como animais adestrados em coleiras pelos guardas, enquanto os operários são macacos presos em gaiolas. Neste sentido, vale ressaltar o grande domínio de Eisenstein de figuras retóricas muito utilizadas em obras de literatura para conduzir seus filmes. Jaques Rancière (cf. 2013) destaca o uso da metáfora, da metonímia e da silepse, que ajudam o cineasta a alcançar os efeitos desejados em suas montagens ${ }^{4}$. Os espiões que se infiltram entre os operários grevistas, por exemplo, são apresentados em planos justapostos a outros em que animais são enquadrados: um espião é como um cachorro, outro é como um macaco, já um terceiro é como uma coruja, e assim por diante. 
Após a renúncia voluntária do trabalho exercido pelos operários e o desacordo nas negociações entre as partes dos proletários e patrões, surge a guerra operária, que representa, tanto no poema quanto no filme, o espírito revolucionário que norteia ambas as obras. No poema, o operário é cercado pelos delatores e agredido em seguida, além de ser cuspido e ter seu braço quebrado. Já no filme, os operários jogam os gerentes da fábrica no rio, ao mesmo tempo em que são vítimas de emboscadas por parte dos espiões das fábricas ou apanham dos guardas.

A estrofe seguinte mostra o ápice da luta de classes travada pelo operário contra seu patrão opressor:

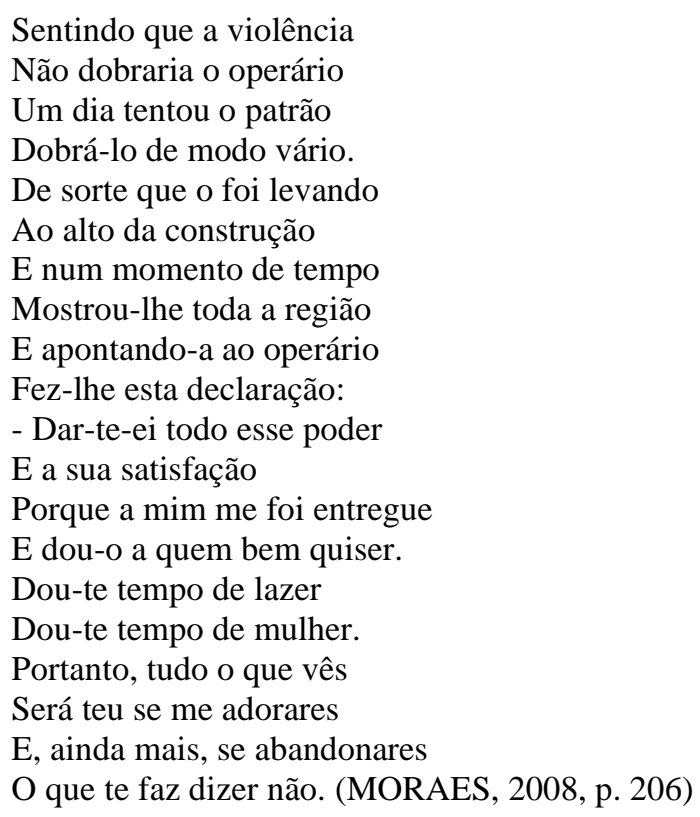

A estrofe acima está diretamente relacionada com o trecho bíblico que introduz o poema, no qual há o relato do momento em que Jesus foi tentado pelo diabo a adorá-lo em troca de poder, o que foi prontamente negado por Jesus, herói da história (Lucas, cap. V, vs. 5-8). O mesmo ocorre no poema por meio do recurso estilístico da associação, recurso semelhante à montagem de atrações usada nos filmes de Eisenstein comentadas acima. A figura de Jesus, o herói, liga-se à do operário, enquanto a figura do diabo, o vilão, conecta-se à do patrão. O desfecho do encontro é o mesmo do encontro bíblico: o operário nega o poder concedido pelo patrão por entender que todo esse poder já lhe pertence, ou seja, adorar o patrão seria o mesmo que cair no paradoxo apontado no início 
do poema, pois culminaria em uma relação de subserviência, quando o operário é livre e detentor do poder da criação.

Além disso, é importante ressaltar o estilo altamente cinematográfico usado para retratar o encontro do operário com o patrão. Esse diálogo entre as duas artes - poesia e cinema -, embora perpasse todo o corpo do poema ${ }^{5}$, atinge seu ápice em definitivo no diálogo travado no alto da construção. Podemos confirmar tal afirmativa pelo jogo de câmeras utilizado na cena mostrada na estrofe, como, por exemplo, o uso do campo/contracampo para marcar a conversa de ambos, bem como o uso de diferentes planos ou enquadramentos, como o plano geral para mostrar a região ou plano detalhe quando o patrão mira seu olhar para o operário. Além disso, há também o uso corrente do verbo "via", que nos remete a diversas imagens, que, justapostas a outras imagens em sequência ou isoladas em um plano, constituem a base do cinema.

Ainda sobre o encontro do operário com seu patrão, há algo de mítico ou utópico. Isso deve-se à analogia, ou à releitura, com o encontro bíblico. Em seu filme, Eisenstein demonstra quão inacessíveis são esses patrões, que simbolizam o modelo econômico capitalista vigente, quando os coloca no mesmo patamar de deuses. Há uma cena em que os acionistas estão reunidos em uma casa para debaterem sobre a carta que contém as reivindicações dos operários. A casa possui uma arquitetura que nos remete aos templos gregos dedicados aos deuses do Olimpo, com suas enormes colunas em estilo dórico. Tal alusão, também de teor mítico, explicita a inacessibilidade desses homens poderosos que, na cena, demonstram repugnância e se sentem ultrajados pelos operários e pela carta de reivindicação.

Seguindo a linha cinematográfica da estrofe que retrata o encontro do operário com seu patrão, a estrofe seguinte expõe a essência do cinema, isto é, o cinema mudo que permite que todo o foco seja dado à imagem pura, destituída de texto - para Vinicius:

\author{
E um grande silêncio fez-se \\ Dentro do seu coração \\ Um silêncio de martírios \\ Um silêncio de prisão. \\ Um silêncio povoado \\ De pedidos de perdão \\ Um silêncio apavorado \\ Com o medo em solidão. \\ Um silêncio de torturas \\ E gritos de maldição
}


Nessa estrofe, há uma explosão de sentimentos distintos - perdão, pavor, solidão e dor - que, em consonância com a imensa carga dramática, são harmonizados com o silêncio ligado às imagens do coração, da prisão, de pedidos de perdão, de torturas etc. Apesar das inúmeras crônicas em que Vinicius defende o estatuto do silêncio como matéria primordial do verdadeiro cinema, nesse poema - mais precisamente nessa estrofe -, temos acesso à demonstração da força que o silêncio possui quando associado à imagem desprovida de textos pelo poeta. Tal demonstração assemelha-se ao experimento de Kuleshov, que justapôs diversos planos com imagens distintas ao plano único do ator Mosjouskine, no qual era possível vê-lo com uma expressão estática, sem qualquer indício de sentimento. No entanto, na medida em que uma imagem qualquer é justaposta à imagem do ator, ele transmite uma emoção correlata à emoção suscitada pela imagem paralela: a imagem de uma criança justaposta à imagem do ator faz com que ele transmita ao espectador um sentimento de tristeza, já a imagem de um prato de comida faz, por sua vez, que o ator transmita uma expressão de fome ${ }^{7}$.

Figura 1: Cena de A greve, com o ator Ivan Mosjoukine, que participou do experimento de Kuleshov

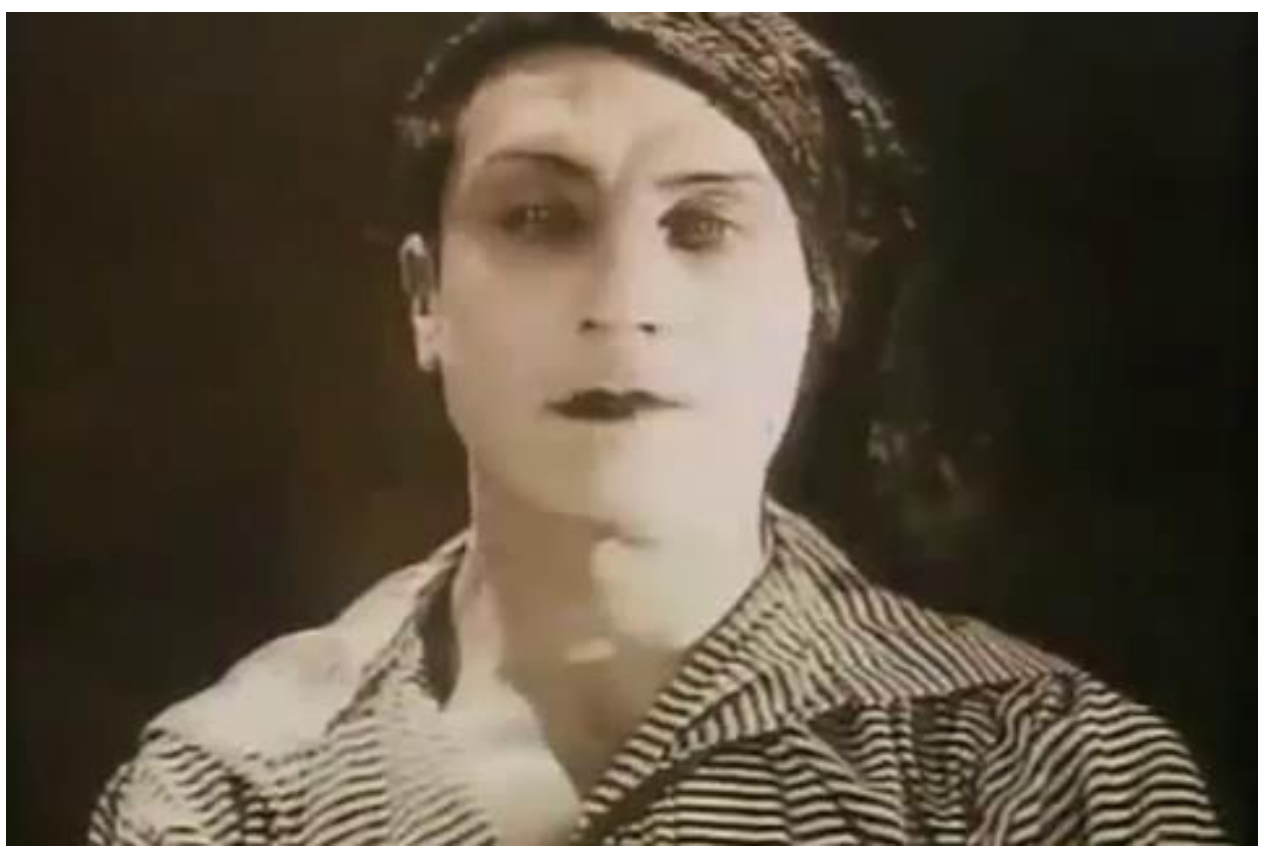

A expressão mostrada na foto não se modifica durante toda a exibição do filme. Fonte: Screenshot de $A$ greve. 
Denominado "efeito Kuleshov", esse efeito é o que Vinicius buscava no que chamava de "verdadeiro cinema" e que ilustra na estrofe. O poeta considerava essa questão tão importante que, no primeiro semestre de 1942, deu início a uma série de debates com outros intelectuais, como Manuel Bandeira, Octávio de Faria, Maria Rita Galvão e Ribeiro Couto, a respeito do cinema mudo em oposição ao cinema falado ${ }^{8}$. Octávio de Faria (1984, p. 137), acompanhado de Plínio Sussekind Rocha, decreta em um artigo publicado pelo Chaplin-Club, por exemplo, que "som e imagem são irreconciliáveis", pois tal reconciliação traz o risco da perda da autonomia da imagem na realização da emoção.

Por fim, o poema encerra-se com a lembrança da voz daqueles que morreram pela causa proletária, cuja luta foi por aqueles que ainda viverão. Estes, operários do futuro, devem deixar de ser operários construídos, ou seja, uma classe forjada para servir e ser explorada pelo sistema capitalista, para se tornarem operários em construção, isto é, devem construir sua própria classe que defenda seus interesses e seja consciente de seus direitos. O filme de Eisenstein é finalizado com a mesma mensagem: "Lembrem-se". Contudo, a última parte do filme é trágica e melancólica, pois há a encenação de um grande massacre, no qual guardas do governo promovem uma chacina nos vilarejos vizinhos. A cena torna-se ainda mais intensa porque o cineasta utiliza, mais uma vez, a montagem de atrações para construir a sequência do massacre: junto aos planos de extermínio dos cidadãos, é mostrado um plano em que um fazendeiro mata um boi de forma cruel e impiedosa. Em vista disso, percebe-se a importância da recuperação da História como auxílio pela causa dos trabalhadores, pois toda a exploração vivida por eles possui antecedentes históricos que ecoam por todo o tempo deixando resquícios de dor, tristeza e injustiça. Além disso, não há como lutar por melhores condições de trabalho se não houver a ação conjunta dos oprimidos, e essa luta começa pela negação daquilo que está posto no sistema vigente, que nem sempre corresponde aos interesses da maioria, isto é, aos interesses da classe operária.

Cabe ainda analisar a métrica do poema "O operário em construção", pois, tendo em vista seu caráter político e sociológico, a obra destaca-se como meio de conscientização e divulgação das ideias propostas por Vinicius de Moraes em seu poema. Os versos que compõem "O operário em construção" são formados por sete sílabas 
poéticas, mais conhecido como redondilha maior. Sobre tal métrica, Celso Cunha e Lindley Cintra, em Nova Gramática do Português contemporâneo (2008), destacam:

\footnotetext{
O verso de sete sílabas ou de redondilha maior foi sempre o verso popular, por excelência, das literaturas portuguesas e espanhola. Verso básico da poesia popular, desde os trovadores medievais aos modernos cantadores do Nordeste brasileiro (...). (CUNHA \& CINTRA, 2008, p. 700)
}

Sendo assim, percebe-se que o uso do recurso da redondilha maior não foi por acaso. $\mathrm{O}$ uso dessa métrica ilustra formalmente o objetivo do poema: demonstrar a luta de classes e a consequente exploração dos trabalhadores pelos capitalistas detentores de poder. Como os explorados são a maioria da população e tendo em vista que o grande capital concentra-se na mão de poucos, a mensagem do poeta deveria ter um grande alcance, se possível atingir, também, como uma música popular, os ouvidos dos opressores, bem como dos oprimidos, principal alvo do poema, que precisariam conscientizar-se e se libertar, já que se encontram alienados pelo sistema capitalista. Portanto, o uso da métrica, neste poema, torna-se de grande importância para a compreensão da obra, visto que demonstra explicitamente - ou seja, no corpo do poema - o mesmo objetivo do operário central, que, ao se libertar, divulga seu novo conhecimento para os demais operários, formando, assim, uma grande corrente popular em nome da liberdade de todos.

\section{Referências}

BAZIN, André. $O$ que é o cinema. Tradução de Eloísa Araújo Ribeiro. São Paulo: Cosac Naify, 2014.

. Charles Chaplin. Tradução de André Telles. Rio de Janeiro: Jorge Zigar Ed., 2006.

Orson Welles. Tradução de André Telles. Rio de Janeiro: Jorge Zigar Ed., 2005.

CATANI, Afrânio Mendes. Vinicius de Moraes, crítico de cinema. In: Perspectivas: Revista de Ciências Sociais, v. 7, 1984. Disponível em http://hdl.handle.net/11449/108241. Acesso em 8 set. 2021.

COELHO, Eduardo dos Santos. Poeta de muitas técnicas. In: MORAES, Vinicius de. Novos poemas, cinco elegias. São Paulo: Companhia das Letras, 2012. p. 
COUSINS, Mark. História do cinema: Dos clássicos mudos ao cinema moderno. Martins Fontes Editora, 2013.

GOMES, Paulo Emílio Sales. O cinema no século. Edição dos textos e notas de Carlos Augusto Calil e Adilson Mendes. São Paulo: Companhia das Letras, 2015.

LOUVEL, Liliane. A descrição pictural: por uma poética do iconotexto. Tradução de Luiz Cláudio Vieira de Oliveira. In: ARBEX, Márcia (Org.). Poéticas do visível: ensaios sobre a escrita e a imagem. Belo Horizonte: Programa de Pós-Graduação em Letras: Estudos Literários, Faculdade de Letras da UFMG, 2006. p. 191-220.

MORAES, Vinicius de. Credo e alarme. Jornal A Manhã, Rio de Janeiro, 1 ago. 1941. p. 5 .

Eisenstein e a teoria do cinema. --, --, 1 fev. 1941, s.p

Do ator. Jornal Última Hora, Rio de Janeiro, 29 set. 1951. p. 9.

- Nova Antologia Poética. Seleção e organização de Antonio Cicero e Eucanaã Ferraz. São Paulo: Companhia das Letras, 2008.

O cinema de meus olhos. Organização e notas de Carlos Augusto Calil. São Paulo: Companhia das Letras: Cinemateca Brasileira, 1991.

PERLOFF, Marjorie. O momento futurista: Avant-garde, avant-guerre e a linguagem da ruptura. Tradução de Sebastião Uchoa Leite. São Paulo: Editora Universidade de São Paulo, 1993.

RANCIÈRE, Jaques. A loucura Eisenstein. In: A fábula cinematográfica. Tradução de Christian Pierre Kasper. Campinas, SP: Papirus, 2013. p. 27-34.

STAM, Robert. Os teóricos soviéticos da montagem. In: Introdução à teoria do cinema. Tradução de Fernando Mascarello. Campinas, SP: Papirus, 2013. p. 54-63.

Recebido em: 02/06/2021

Aceito em: 03/09/2021

\footnotetext{
${ }^{1}$ Conferir a crônica "Credo e alarme", de Vinicius de Moraes, de 1 de agosto 1941. Disponível no site oficial do poeta: https://www.viniciusdemoraes.com.br/pt-br/cinema/credo-e-alarme. Acesso em 08 set. 2021.

${ }^{2}$ Conferir a crônica "Eisenstein e a teoria do cinema", de Vinicius de Moraes, de 1 de fevereiro de 1941. Disponível no site oficial do poeta: http://www.viniciusdemoraes.com.br/pt-br/cinema/eisenstein-e-teoriado-cinema. Acesso em 08 set. 2021.

3 A respeito da importância da direção no trabalho dos atores em cinema, ver a crônica "Do ator", de Vinicius de Moraes. Disponível no site oficial do poeta: http://www.viniciusdemoraes.com.br/ptbr/cinema/do-ator. Acesso em: 08 set. 2021.
} 
${ }^{4}$ Conferir “A loucura Eisenstein”, em A fábula cinematográfica (2013), de Jacques Rancière.

${ }^{5}$ Podemos ver um exemplo desse diálogo do poema com a arte cinematográfica nas diversas vezes em que objetos de menor valor dos operários, percebidos numa espécie de plano detalhe, são associados a objetos de maior valor pertencentes ao patrão e que se ligam aos efeitos da montagem de atrações, que são constantes nos filmes de Eisenstein.

${ }^{6}$ Em seu ensaio “A descrição 'pictural': por uma poética do iconotexto”, Liliane Louvel (2006, p. 200) evidencia que "uma descrição será dita "pictural" quando a predominância de "marcadores" de picturidade que permite "um efeito de expansão, de dilatação, ela resiste à 'linearidade' acrescentando um espaço, aquele da imagem mental, cuja extensão terá como limites apenas a imaginação". Podemos presenciar essa expansão pelo uso de marcadores linguísticos do poema ligados à visão - uso de verbos como "mostrar", "apontar" e "ver", por exemplo - e que expandem o cenário inserindo o leitor na construção desse quadro ao presenciar uma cena descrita por Vinicius como se estivesse, na verdade, operando uma câmera cinematográfica.

${ }^{7}$ Sobre o experimento de Kuleshov, conferir “Os teóricos soviéticos da montagem”, em Introdução à teoria do cinema (2013), de Robert Stam, ou "Montagem proibida", em O que é cinema (2014), de André Bazin.

${ }^{8}$ A respeito do debate Cinema mudo versus Cinema falado iniciado por Vinicius de Moraes, conferir "Vinicius de Moraes, crítico de cinema" (1984), de Afrânio Mendes Catani. 